(3) Calcarenite, limestone and/or calcareous clays and siltstones with a rich marine fauna which includes Hantkenina.

(2) Siltstones commonly lignitic and purple in colour with abundant Cyclammina.

(1) Medium to coarse quartz sandstone, markedly carbonaceous (including seams of lignite in some places) at the base.

- Jurassic.

The difficulty was that in earlier discussions this general sequence was not well understood ; indeed, as pointed out above, the order of the beds (2) and (3) was reversed by some authors. The correction of this error, the disccvery of Victoriella at Brown's Creek and of Hantkenina at Torquay provide three pieces of evidence which support one another and allow correlation of sections many miles apart to be made with confidence. (Raggatt and Crespin, 1952).

H. G. RagGatt.

\title{
REFERENCES
}

Raggatt, H. G. and Crespin, Irene, 1952. Geology of Tertiary Rocks between Torquay and Eastern View, Victoria. The Australian Journal of Science, xiv, 143-7.

Glaessner, M. F., 1951. Three Foraminiferal Zones in the Tertiary of Australia. Geol. Mag., lxxxviii, 273-284.

1952. Correspondence. Geol. Mag., Ixxxix, 228-9.

Crespin, Irene, 1952. Correspondence. Geol. Mag. Ixxxix, 225-8.

Department of Natronal Development, ACTON

CANBFrRA, A.C.I.

8th October, 1952.

\section{LINEATION IN THE SHETLAND ISLANDS}

SIR,-In his paper on "A Tectonic Analysis of the Muness Phy llite Block of Unst and Uyea, Shetland" (Geol. Mag., 1952, 263) Dr. D. Flinn gives some interesting particulars with regard to the dimensions of pebbles in conglomerates. So far as the writer knows, such particulars had not previously been given about the constituents of any Scottish conglomerate in an area of lineation, and they have an important bearing on the theory of this subject.

The average dimensions of more than 50 specimens were found to be in the ratio $15 \cdot 3$ parallel to the lineation, $2 \cdot 3$ normal to the lineation, but in the plane of schistosity, and 1.0 across the schistosity. Dr. Flinn infers that if the specimens were originally roughly of the same diameter in all directions, they have been elongated, parallel to the lineation, to about 4.6 times their original length.

In a paper published by the writer in 1948 (Quart. Journ. Geol. Soc., civ, 99) other instances were mentioned where it had been found that lineation and the extension of pebbles were parallel. In most of these cases it was impossible to infer, from the published data, whether the joint direction was $a$ or $b$. A description by A. Kvale, however (1945, Norsk. Geol. Tidsskr., $x x v, 193)$ refers to an instance, in the Bergsdalen quadrangle, in Norway, where there is no possible doubt that both the lineation, and the main extension of pebbles. is in the $a$ direction.

Dr. Flinn, on the other hand assumes both structures to be in the $b$ direction, and explains the extension by rolling. This is the "orthodox" explanation, but it does not seem to be easily intelligible. A pebble in a matrix which is undergoing distortion may be expected to alter its dimensions, but surely it will lengthen them more in the direction of transport than in either of those which are at right angles to it. By "transport "one means the relative movement of two superimposed layers, and if Dr. Flinn is right, this must be either from west to east, or from east to west, corresponding to 
what he supposes to be the $a$ direction. The pebbles which he describes are, however, lengthened on the average $25^{\circ}$ east of north, with a plunge of $24^{\circ}$ in that direction.

The lineation of the metamorphic rocks in certain parts of Shetland was studied during the Geological Survey's rcutine examination of these islands (T. Robertson, 1938, "Observations on the Direction of Lineation in parts of Shetland," Summ. Progr. Geol. Surv. for 1936, part 2, p. 75). This applies, in particular, to an irregular belt, running across the group, from Vementry, west of the "Mainland", to the Outer Skerries, well to the east of the same main constituent, a total distance of about 25 miles. Throughout the belt the direction valies only from nearly due north and south to north-east. Dr. Flinn's lineations, if continued in thei own line, would fit in well with Robertson's observations, and one may infer that there is a certain regularity, probably applying to all the lineated part of Shetland.

Reverting to the simile, used in the writer's 1948 paper, of the movement of a pack of cards, lying on a flat table, it may be suggested that the uppermost cards have moved either north or south, in relation to those below. This can only represent very roughly what has happened in Shetland, in view (1) of the lineation dips, and (2) of the large displacements discussed by Read (1934, Quart. Journ. Geol. Soc., xc, 637) and others. It implies an $a$ lineation, but appears to the writer to give a better explanation of the extension of the pebbles described than that of Dr. Flinn's paper.

62 Greenbank Crescent,

E. M. Anderson. EDINBURGH.

October, 1952.

\section{MUGEARITES AND OLIGOCLASE-BASALTS}

SIR,-My old friend Professor Walker, in his recent article " Mugearites and Oligoclase-Basalts" (Geol. Mag., lxxxix, p. 337), refers to my description of mugearites in "The Geology of North Ayrshire" (Mem. Geol. Surv., 1930, pp. 105-8) but, owing to a temporary oversight (for which he has hastened to express regret by air-mail), fails to direct his readers' attention to p. 89 of that publication, where a reference will be found to a paper entitled "The Classification of Scottish Carboniferous Olivine-basalts and Mugearites" (Trans. Geol. Soc. Glasgow, xviii, pt. ii, 1928, p. 324). In this paper I devoted four pages to the history of the classification of Scottish mugearites, and drew attention to H. S. Washington's "olivine-oligoclaseandesites " of Hawaii, to H. H. Thomas's pre-Upper Llandovery mugearites of Pembrokeshire, and to A. K. Wells's views (of 1924) on the classification of mugearites. I dealt with the use of the name mugearite in Geological Survey publications in more detail than Professor Walker, and worked out a comprehensive definition of the term which seems to differ little from the one he now proposes. At a later date I adopted the current view that mugearite is a special variety of trachybasalt (op. cit., 1928, p. $349 ; 1939$, p. 89).

Professor Walker's article is timely, and will prove of interest to those who deal with volcanic petrology. I agree that the abandonment of the term "oligoclase-andesite" should be considered by Hawaiian petrologists. I believe, however, that no definition of mugearite will make it less difficult to solve two problems: (1) the naming of rocks transitional from mugearite to fine-grained basalt with fluxional parallelism of feldspars ; (2) the recognition of the original composition of the tiny sub-parallel albitic feldspars of lavas that resemble mugearites but are not "fresh-looking" (op. cit., 1928, p. 348). In the case of (1) the term " basaltic mugearite " is often useful.

19 Grange Terrace,

A. G. MACGregor.

EDINBURGH.

13th October, 1952. 